Pamiętnik Literacki 2018, 3, s. 51-69

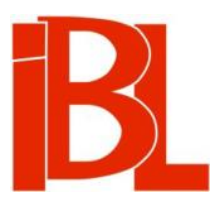

Homoerotyzm, mimesis i "Kunst der Fuge". Twórczość André Gide'a ("Korydon", "Fałszerze") w literaturze polskiego Dwudziestolecia międzywojennego

Wojciech Śmieja 
Pamiętnik Literacki CIX, 2018, z. 3, PL ISSN 0031-0514

DOI: $10.18318 / \mathrm{pl} .2018 .3 .4$

WOJCIECH ŚMIEJA Uniwersytet Śląski, Katowice

\section{HOMOEROTYZM, MIMESIS I „KUNST DER FUGE” TWÓRCZOŚĆ ANDRÉ GIDE’A („KORYDON”, „FAŁSZERZE”) W LITERATURZE POLSKIEGO DWUDZIESTOLECIA MIEDZYWOJENNEGO}

Trzech wielkich pisarzy polskiego modernizmu: Jarosława Iwaszkiewicza, Jerzego Andrzejewskiego i Witolda Gombrowicza ${ }^{1}$, nawiedza duch André Gide’a - zaświadczają oni o tym w swoich zwierzeniach autobiograficznych. Mocują się, spierają z nim, nawiązują do jego twórczości, komentują ją, a także - naśladują. I nie chodzi tu o mimetyzm stylistyczny, ale o naśladownictwo rozumiane w sensie etymologicznym tego słowa - podążanie czyimiś śladami, tropienie, lecz też imitowanie, przebieranie się za kogoś. Wszyscy ci trzej pisarze zachowują pewną wiarę w magię, przekonanie, że odwiedzając miejsca, w których mieszkał Gide, wejdą z nim w jakiś tajemniczy kontakt. Tak więc np. Gombrowicz w swoim dzienniku z 1966 roku wyznaje:

W Royaumont, pod Paryżem, trzy miesiące spędziłem. Potem uciekłem przed jesienią, naprzód w okolice Cannes, do La Messuguière. Zajmowałem pokój, w którym Gide mieszkał przed laty. Moja ścieżka wstępuje na koniec na ślad ludzi, dobrze mi znanych od dawna, jakbym dosięgał ich fizycznie post mortem, i odzywa się we mnie głos: byłeś wygnany ${ }^{2}$.

Iwaszkiewicz sygnuje Panny $z$ Wilka „Syrakuzy, kwiecień 1932”. Nie byłoby w tym nic dziwnego - to wszak częsta praktyka Iwaszkiewicza - ale najwidoczniej to akurat miejsce jest dlań ważne w sposób szczególny: w kilkadziesiąt lat później pisarz wraca do niego, przyciaga go ono. Notuje w dzienniku 17 IV 1964:

byłem pełen wrażeń z Syrakuz - a raczej wspomnień niż wrażeń, bo wszystko takie inne i zmienione. Tylko hotel Des Etrangers stoi jak stał, spokojny i zwyczajny, i bynajmniej nie dumny z tego, że mieszkał tam Gide, i Karol [Szymanowski], i ja... ${ }^{3}$

Andrzejewski natomiast w Dzienniku paryskim wyznaje z dumą: „W moim hotelu mieszkał przez wiele lat André Gide, a ostatnio Iwaszkiewicz z żoną"4.

Wszyscy trzej pisarze - wystarczy prześledzić ich dzienniki i/lub korespondencję - znają twórczość Gide’a, czytają ją na bieżąco, konfrontują się z nim, próbują się wobec niego określić, przymierzają się niejako do niego, co szczególnie widać

$1 \quad$ Dotyczy to również J. Lechonia czy Z. Mycielskiego.

2 W. Gombrowicz, Dziennik 1953-1969. Posł. J. Franczak. Kraków 2011, s. 849.

3 J. Iw a szkiewicz, Dzienniki 1964-1980. Oprac., przypisy A. i R. Papies cy, R. Romaniuk. Wstęp A. Gronczews ki. Warszawa 2011, s. 46.

4 J. Andrzej ew s ki, Dziennik paryski. Wstęp, oprac. W. Le w a n d o w s ki. Warszawa 2003, s. 18. 
u Iwaszkiewicza, który też często jest przymierzany jako „polski Gide”. Autor Przyjaciół poniekąd literacką siłą ciążenia własnej - jakże nienormatywnej - biografii, małżeństwa, pozycji artystycznej dokonuje autorefleksji, życiowych i literackich resumées w zestawieniu $z$ Gide’em. Poświęca temu całą, niezwykle interesująca notatkę z 22 I 1955. Zacytuję tylko początek:

Zabrałem z sobą Journal Gide’a (1939-1949) bez wielkiej myśli, że będę to czytał, ale jakoś narzuciło mi się to i czytam już nieprzerwanie jednym ciagiem, bo to $z$ dziennikiem to jak z czereśniami, póty się bierze jedną za drugą, póki się wszystkiego nie zje. Oczywiście - co tu dużo ukrywać - w dzienniku Gide'a pociaga mnie najwięcej to, co zbliża go do mnie, porównanie z moim losem i moimi przeżyciami, nawet $\mathrm{z}$ moim d zi e n n i k i e m. Są pewne punkty styczności niewątpliwie, ale jakież olbrzymie różnice! ${ }^{5}$

Nazwisko autora Pokarmów ziemskich pojawia się często także w dzienniku Jana Lechonia, korespondencji Pawła Hertza, Zygmunta Mycielskiego i Jerzego Zawieyskiego ${ }^{6}$. Aleksander Janta-Połczyński wybrał się do Gide’a, by przeprowadzić $\mathrm{z}$ nim długi wywiad? .

Wszyscy wspomniani twórcy to osoby seksualnie nienormatywne, dla których Gide jest pisarzem emblematycznym, być może nawet instancją moralną ${ }^{8}$ Chyba jeszcze w większym stopniu niż Marcel Proust, którego „teorie seksualności” wydają się bardziej zawoalowane i zniuansowane, a on sam w swoim dziele - inaczej niż Gide - mówi jako postać heteroseksualna ${ }^{9}$. W swoim dzienniku autor Symfonii pastoralnej wspominał spotkanie z Proustem (14 V 1921), który go pouczał: „Może pan wszystko opowiedzieć pod warunkiem, że nie powie pan: "j a»"10, co Gide komentuje dość buńczucznie: „To nie mój przypadek” ${ }^{11}$. Tym, co sprawiło, iż stał się on takim człowiekiem, była w połowie lat dwudziestych publikacja trzech bardzo istotnych książek: powieści Fałszerze, autobiografii Jeżeli nie umiera ziarno... i ujętego w formie filozoficznego traktatu zatytułowanego Korydon. Cztery dialogi sokratyczne (1924) ${ }^{12}$. Spośród tych trzech pozycji to właśnie Korydona sam Gide nazywa swoim najważniejszym dziełem, a wstępu do niego chciałby użyć jako okolicznościowego exposé po przyjęciu go do Akademii Francuskiej ${ }^{13}$. Myśl o znaczeniu Korydona powtarza w rozmowie $\mathrm{z}$ Jantą-Połczyńskim, uzasadniając:

jest to książka, która oddała wielu młodym i zgubionym ludziom usługę pogodzenia ich z własną naturą. Okazało się także, że jest to temat nieobojętny wcale dla większej o wiele ilości osób, niżby się to c zew s ki. Warszawa 2007, s. 452.

(

\footnotetext{
A. J a n t a, Spotkanie z André Gide'em. W: Losy i ludzie. Spotkania-przygody - studia: 1931-1960. Londyn 1961, s. 121-133.
}

8 „Moralistyczny” wymiar dzieła Gide’a i jego recepcji prześledził P. Pollard w pracy André Gide: homosexual moralist (New Haven, Conn., 1991).

9 O „homoerotycznej” recepcji Prousta pisze ciekawie B. C za r n e c k a w rozdziale Homoseksualna enklawa (Proust) swojej rozprawy Ruchomy na szali wagi. Lechoń homotekstualny (Toruń 2013).

W języku polskim dostępne są jedynie fragmenty: A. Gi d e, Korydon. Cztery dialogi sokratyczne (fragment). Przeł. W. Śmi e ja. „Ha!art” 2004, nr 19.

13 A. Gide, Journal. T. 2: 1926-1950. Éd. M. Saga ert. Paris 1997, s. 842, 1017. 
komukolwiek, a już na pewno także mnie samemu, mogło z początku wydawać. Jest to również książka, która uratowała niejedno życie ${ }^{14}$.

Gide w Korydonie dość mocno sprzeciwia się dominującym poglądom naukowym na homoseksualizm (internalizował je Proust) i pokazuje, że wzorowana na greckich ideałach relacja pederastyczna jest nawet bardziej wartościowa i bardziej „męska” niż waloryzowana społecznie „mieszczańska” heteroseksualność. Gide innymi słowy mówi to, czego nikt nie waży się pomyśleć, i to, co mówi, rezonuje niezwykle szeroko. Być może, nasze wywody należy rozpocząć od stwierdzenia, że rola, która polscy - i określani jako homoseksualni - twórcy przypisali Gide’owi, nie stanowi o jakiejś specyficznej pozycji tego autora właśnie w Polsce, bo, jak np. podkreśla badaczka historii homoseksualności, Florence Tamagne, „nietzscheański” Immoralista był książką namiętnie czytaną i komentowaną, ale to Korydon spowodował, że Gide'a mianowano pisarzem homoseksualnym ${ }^{15}$. Po publikacji tego traktatu Gide stał się niejako „rzecznikiem” francuskich homoseksualistów ${ }^{16}$ :

Konsekwencją tego [tj. opublikowania Korydona - W. Ś.] był fakt, że francuscy homoseksualiści dość szeroko identyfikowali się z ideami Gide’a, mimo że były one dość specyficzne i nie można było po prostu zaadaptować do życia większości z nich. Ponadto z pola refleksji zupełnie eliminowały one lesbianizm, który Gide’a zwyczajnie nie interesował. [...]

Gide starał się zrehabilitować homoseksualność, przez co wpisał się w długą tradycję tak dobrze reprezentowaną w Niemczech przez grupę Adolfa Branda, Gemeinschaft der Eigenen czy nauczycieli takich jak Gustav Wyneken. Ogólny ton eseju [Gide’a] trąci poczuciem wyższości. Pederaści to intelektualiści, artyści, esteci, potrafiący odróżnić prawdziwe piękno, którzy bardziej dbają o ducha niż o ciało. Czy dzieło Gide'a jest zatem oryginalne? We Francji tak, ponieważ wcześniej takiej obrony homoseksualności nie było, a dzieło Prousta jednak ukrywa jej temat. Niemniej w roku 1924 Korydon był dziełem raczej mało współczesnym. Pederastia nie stanowiła pierwszorzędnej kwestii w Dwudziestoleciu, przeciwnie, tym, czego potrzebowano, było uznanie osób homoseksualnych w ogóle, bez względu na nazwanie ich inwertytami, pederastami czy sodomitami, bez wyróżniania rozmaitych typów i tendencji [co Gide robi w Korydonie - W. Ś.]. Dla wszystkich anonimowych homoseksualistów Korydon mógł nieść jakieś pocieszenie, ale prawie żadnej nadziei. Niewielu odnalazłoby się w tym portrecie moralnego czy nawet moralistycznego pederasty, który usprawiedliwia „grzech” w oparciu o argumenty artystyczne czy pedagogiczne. [...]

Choć powieści [Gide'a] legitymizują homoseksualność, to Korydon stanowi punkt zwrotny w mówieniu o homoseksualności wprost w okresie międzywojennym, niemniej nazywanie Gide’a bojownikiem za sprawę byłoby przesadą. Zatrzymuje się on na pozycji intelektualisty, który broni swojej wyjątkowości. Jego argumentacja zasadniczo zmierza do ukazania homoseksualności jako uprawnionej i wymagającej tolerancji, a także do tego, by uznać w osobie homoseksualnej jej pojedynczość, kogoś, kto wybrał własną drogę i przez to, w pewnym stopniu, jest jednostką wyższą od ogółu ${ }^{17}$.

Przypomnijmy jeszcze, iż Korydon zaowocował w leksyce francuskiej powstaniem kilku nowych słów. Le Vocabulaire de la homosexualité masculine odnotowuje np. takie formy, jak „des Corydons” na oznaczenie męskich homoseksualistów, przymiotniki „corydonesque” $i$ „corydonien”, rzeczowniki „corydonism”, „Corydonia” (sugerowany jako tytuł czasopisma), czasownik zwrotny „s'encorydonner” ${ }^{18}$. Na

F. Ta magn e, A History of Homosexuality in Europe: Berlin-London-Paris. 1919-1939. T. 1-2.

New York 2006, s. 95.

Zob. ibidem, s. 94.

Ibidem, s. 97.

18 C. Courouve, Vocabulaire de l'homosexualité masculine. Paris 1985, s. 91-92. 
marginesie można zauważyć, że Korydon bardzo szybko i głośno wybrzmiał nawet w sowieckiej Rosji, gdzie słynna literaturoznawczyni i krytyczka Lidia Ginzburg opublikowała polemiczne Razgawory o lubwi - wśród nich czwarta rozmowa jest pewnego rodzaju odpowiedzia na Korydona, czytanego i krytykowanego przez Ginzburg w notatkach $z$ lat 1925-1926.

Nic dziwnego zatem, że to właśnie Korydon stanowi utwór, do którego szczególnie często będę się odwoływał w tym szkicu. Dlaczego tak się dzieje, tłumaczą istotne konstatacje Didiera Eribona przeznaczającego literaturze bardzo szczególne miejsce w niezastapionych Réflexions sur la question Gay (Rozważania o kwestii gejowskiej). Eribon, podobnie jak cytowana już Tamagne, zauważa, iż Korydon wpisuje się - oraz przenosi na inny poziom dyskusji i w odmienne, by tak rzec, otoczenie dyskursywne - w sięgająca lat siedemdziesiątych XIX wieku tradycję apologizowania homoseksualności ${ }^{19}$ (lub, by nie popadać w anachronizm, „męskiej przyjaźni”). Inaczej jednak niż autorka Histoire de l'homosexualité en Europe (Historia homoseksualności w Europie) - Eribon twierdzi, że tradycja, do jakiej odwołał się Gide, to tradycja zapoczatkowana w wiktoriańskiej Anglii przez wielkich apologetów starożytnej pederastii: Johna Addingtona Symondsa (Gide prawdopodobnie go nie czytał) i Edwarda Carpentera, którego antologie cytatów autor Korydona znał ${ }^{20}$. Eribon podważa tezę Michela Foucaulta dotyczącą tego, iż twórczość pisarzy homoseksualnych (Foucault mówił o Gidzie i Oskarze Wildzie) stanowi reakcję na teorie psychiatryczne, ale dzieje się właśnie odwrotnie: to teoria psychiatryczno-seksuologiczna jest reakcją na uprzednie wytworzenie tożsamości opartej na antycznych odwołaniach ${ }^{21}$. Jak zwięźle ujmuje to tytuł (Les Grecs contre les psychiatres 〈Grecy przeciw psychiatrom $\rangle$ ) jednego $z$ rozdziałów książki Eribona ${ }^{22}$ : literatura służyła oczywiście, w wymiarze elitarnym, czego wyraz stanowi dynamika skandalu księcia Eulenburga, o której pisałem w innym miejscu - za dyskurs umożliwiający skonstruowanie modelu męskiej relacji jednopłciowej (pederastii) odmiennego od zmedykalizowanej homoseksualności jako cnoty, jako (jak by to ujął Leo Bersani) wartości „użytecznej społecznie”23.

Wydaje się, że procesy Wilde’a i księcia Eulenburga z przełomu XIX i XX wieku wyznaczają w sporze psychiatrów z Grekami moment kluczowy: burżuazyjna opinia publiczna odrzuca „arystokratyczna”” opowieść o pederastii i uznaje za panującą tę patologizująca, medyczną o homoseksualizmie ${ }^{24}$. Ta ostatnia w latach dwudziestych XX stulecia cieszy się już popularnością i reprodukuje ją w swoim dziele Proust, przeciwko któremu m.in. Gide pisze Korydona.

Być może, najwyższa pora postawić główną tezę tego tekstu. Otóż brzmi ona następująco: w polskiej przestrzeni literackiej i kulturowej końca XIX wieku nie było

A jeśliby uznać za jej protoplastę J. J. Winckelmanna, to jeszcze 100 lat wcześniej.

D. Erib o n, Réflexions sur la question gay. Paris 1999, s. 309.

Ibidem, s. 272.

Ibidem.

L. Bers ani, Homos. London 1995, s. 113.

Pisałem na ten temat $\mathrm{w}$ pracy Homoseksualność i polska nowoczesność. Szkice o teorii, historii i literaturze (Katowice 2015, s. 105-156). 
"Greków”, a mówiąc mniej metaforycznie - odwołanie się do kultury greckiej, tak typowe dla świata anglosaskiego i kultury niemieckiej jako źródłowej dla kształtowania się „opowieści pederastycznej”, nie zaistniało. $Z$ niewielkim natomiast opóźnieniem przyswojono psychiatryczne teorie homoseksualizmu - pierwszy przekład rozprawy Richarda von Kraffta-Ebinga ukazał się w 1888 roku. Szybko znalazły one odzwierciedlenie w literaturze (wystarczy przywołać sposoby pisania o skandalu Wilde'a - szczególnie jak robił to w Polsce jego wielki popularyzator: Adolf Nowaczyński) i dyskursie publicznym (tu znowu przypomnę skandal Eulenburga). Tak więc w polskich sporach wokół relacji męsko-męskich zabrakło jednej strony, jednej tradycji. W Dwudziestoleciu międzywojennym taka tradycja jest z opóźnieniem - formowana jako swego rodzaju proteza. Owej protezy dostarcza Korydon i, szerzej, dzieła Gide’a jako pisarza reprezentującego kulturę francuską uznawaną w liberalnych i opiniotwórczych kręgach we wspomnianej epoce za wzorcową, historycznie bliską Polsce, a zarazem za najbardziej rozwinięta, najnowocześniejszą. Powiedzenie, że Korydon i inne dzieła Gide’a w ogóle umożliwiają nazywanie homoseksualności w polskiej prozie Dwudziestolecia, byłoby z pewnościa przesada, ale nie jest nią stwierdzenie, że bez Korydona i Gide’a miałoby ono zupełnie inny kształt i zakres. Dalej postaram się przedstawić kilka przykładów tego typu intertekstualnych relacji.

Trudno jako autora homoseksualnego potraktować Stanisława Ignacego Witkiewicza, nie można mu jednak odmówić dystansu do konwenansów społecznych i konserwatyzmu obyczajowego, a także zainteresowania homoseksualnością (widocznego już w 622 upadkach Bunga). Pożegnanie jesieni z 1927 roku jest najprawdopodobniej chronologicznie pierwszym utworem literackim, który odwołuje się do Korydona. Co więcej, stanowi nie tylko dowód oddziaływania dialogów Gide’a, ale też w celny, choć ironicznie pomniejszony, sposób zdaje się potwierdzać postawioną przeze mnie tu tezę. German Ritz swego czasu zauważał, że „tożsamość homoseksualna” "generuje się [...] w odzyskiwaniu języka”25. Tak właśnie Korydon dostarcza języka - w tej funkcji pojawia się w Pożegnaniu jesieni. Kiedy hrabia Józef Łohoyski czyni awanse Atanazemu Bazakbalowi pod wpływem kokainy, próbuje nawiązać $z$ nim rozmowę poprzez język dialogów Gide’a:

- Kocham cię, Taziu. Próbowałem z takimi... wiesz? Ale nie mogę. To jest pederastia - świństwo. Ty nie wiesz jeszcze, czym jest przyjaźń, ale na to trzeba się zespolić, zlać w jedno. Jesteś komunista - wiem - ale wszystko jedno. Jesteś piękny psychofizycznie, tylko ty jeden. Ach, cóż to za świństwo jest kobieta! Gdybyś chciał mnie zrozumieć bez uprzedzeń, weszlibyśmy razem w ten świat... Przeczytaj Corydona - masz!

Wlepił Atanazemu małą książeczkę Gide’a.

- Nie chcę. Słyszałem o tym. Na to mnie nie weźmiesz. Nie czuję do ciebie wstrętu, ale żałuję cię, choć sam jestem w stanie zupełnego upadku.

- Też! Ach, ty nie wiesz! To nie jest upadek, tylko inne życie, jak na innej planecie. Ale bez ciebie nie mogę; nie mogę być tak samotnym ${ }^{26}$. 1997, nr 3, s. 43.

26 S. I. Witkiewicz, Pożegnanie jesieni. Oprac. A. Mi cińska. Warszawa 1992, s. 210. 
Łohoyski to homoseksualista i kokainista, arystokrata, który w obliczu rewolucji szuka „sztucznego raju”. Jak komentuje Tomasz Kaliściak:

Kokaina stwarza utopię dla homoseksualistów, którzy nie znajdują miejsca w społeczeństwie ogarniętym paniką przed innością. Literackim wykładnikiem tego raju jest Corydon André Gide’a, którego hrabia podsuwa Bazakbalowi podczas „homo coco”. Kokaina pozwala więc Łohoyskiemu zaakceptować własną seksualność i stworzyć przestrzeń dla jej ekspresji ${ }^{27}$.

Niestety, romansu z Atanazym nie będzie, arystokrata zwraca się więc ku młodym góralom, co budzi wstręt księcia Prepudrecha - patrząc jak Łohoyski „obejmuje dwóch [...] parobków”, monologuje: „Corydon Gide’a w zastosowaniu do tych pijanych zwierząt [...]"28. Nie zniechęca to jednak Łohoyskiego, gdyż ten, zdystansowany wobec swego dotychczasowego środowiska:

powrócił znowu do uwodzenia młodych górali, a nawet zaczął pisać w ludowym dialekcie coś w rodzaju popularnego Corydona dla klas niższych: Dialog gazdy z diabłem o zadku - taki miał być tytuł tego dzieła. Pomagał mu w tym Jaś Baraniec, nawrócony zupełnie na nową wiarę w „wyższą” przyjaźñ ${ }^{29}$.

Nietrudno w tym, co i jak Witkacy pisze o Korydonie, wykryć zamiar ironiczny, kpinę. Witkacy był au courant $\mathrm{z}$ ówczesnymi dyskusjami i sporami, nieraz snobistycznymi, którym tyle jego powieści i dramaty zawdzięczają. Jeśli jakieś nazwisko, tytuł, idea pojawiają się u niego, stanowi to dowód, że znajdują się one w kulturalnym obiegu jego środowiska - dziełko Gide’a nie jest tu wyjątkiem. Pojawiający się w Pożegnaniu jesieni pomysł, by stworzyć „popularnego Corydona dla klas niższych”, oczywiście, stanowi kpinę z Gide'owskiej idei „arystokratycznej” apologii homoseksualizmu - idei zapewne zbyt odległej od życia, do którego „bebechowatości” dopiero trzeba ją sprowadzić, pisząc „dialogi o zadku”. Dla potwierdzenia tej tezy sięgnijmy do prywatnej korespondencji autora 622 upadków Bunga, w której referuje on żonie swoją opinię o dialogach Gide'a. Tak więc np. Witkacy w liście do żony z 26 IV 1926 stwierdza: „Corydon b. nudny i nie b. ciekawy”30. Natomiast kilka lat później w liście do niej z 23 II 1929 zamieszcza „poemat prozą, w którym wciąż pobrzmiewać będzie wrażenie, jakie zrobił na nim Gide:

Jak latarnia morska chłopiec wypiętrza sie przy łóżku,

Rżnę go jak Cocteau, Jacob i sam André Gide,

A potem na mszę walę, też jak oni.

I potem borsuczem sadłem maszczę białe chłopców półkule,

Niby słoneczne ule,

I myślę o słodkiej Matce Boskiej,

Jak o mej prywatnej Pallas Atene,

I w stosunku do Niej jestem już czysty.

$\mathrm{O}$, sadło borsucze -

$\mathrm{O}$, półkule -

Jak Cocteau, Jacob i Gide ${ }^{31}$.

T. Kaliścia k, Płeć pantofla. Odmieńcze męskości $w$ polskiej prozie XIX i XX wieku. Warszawa 2016, s. 119-120.

Witkiewicz, op. cit., s. 314.

Ibidem, s. 329.

S. I. Witkiewicz, Listy do żony. (1923-1927). Przygot. do druku A. Micińska. Oprac., przypisy J. De gler. Warszawa 2005, s. 93.

S. I. Witkiewicz, Listy do żony. (1928-1931). Przygot. do druku A. Micińska. Oprac., przypisy J. Degler. Warszawa 2007, s. 74. 
Cocteau, Jacob i Gide reprezentują tu ten sam, pederastyczny, wysoki model homoseksualności - Witkacy go wykpiwa. Wierszyk to mała profanacja, jest „bebechowaty", czystość i wzniosłość to poza: prawdziwa okazuje się praktyka seksualna (pedykacja; borsucze sadło jako lubrykant oraz ludowy środek wzmagający potencję seksualna), która staje się „brudna” dopiero wtedy, gdy próbuje się ją „oczyścić” przez bigoteryjna praktykę religijno-ekspiacyjną albo sublimujący i intelektualny kult antycznej bogini, stanowiące w gruncie rzeczy nic więcej jak niewiarygodna maskaradę. Maskarada ta ponadto ma wyraźnie cechy odtwórcze: pragnienie homoseksualne odczuwane przez bliżej nieokreślony podmiot w niejasny sposób wiąże się $z$ gwarancjami wysokiego poziomu wyrafinowania kulturowego (francuscy pisarze), jego charakter jest zatem statusowy ${ }^{32}$. Przedrzeźnia się tu raczej formę poetyki niż konkretnego twórcę, choć skojarzenia z Karolem Szymanowskim czy Jarosławem Iwaszkiewiczem same się nasuwają.

Jeśli słusznie interpretuję intencję wierszyka, to trzeba powiedzieć, że Witkacy nie znajduje się daleko od Tadeusza Boya-Żeleńskiego, który w felietonie Przedwiośnie? zdaje swoim czytelnikom relację z lektury Korydona, popularyzując przy okazji w szerszym kręgu odbiorczym dzieło Gide’a. Boy, jak to już w innym miejscu starałem się wykazać ${ }^{33}$, będąc daleko od powszechnego braku akceptacji dla „mniejszości seksualnych”, czego wyrazem jego kampania za dekryminalizacją homoseksualizmu, buduje w swoich wypowiedziach dość liczne figury dystansu i lekceważenia. Felieton Boy zaczyna od bardzo silnej deklaracji, że „oblega go pewna kwestia, nastręcza [mu] się wszędzie”, ale - uwaga - „raczej w książkach niż w życiu" ${ }^{34}$. I to rozróżnienie rozciąga się na cały felieton: kwestia homoseksualności i jej ewentualnej dekryminalizacji dotyczy Boya jako zagadnienie literackie czy dyskursywne. Korydon skłania autora Słówek do refleksji dotyczącej właśnie języka (i) literatury w pierwszej mierze. Rzecz idzie o możliwość wyrażenia doświadczeń wcześniej ukrywanych, kryminalizowanych - Boya interesuje faktycznie lokucyjny potencjał oferowany przez dzieło Gide’a, niejako wbrew samemu autorowi i jego „dyspozycji psychologicznej”:

Rzecz jasna, że te poglądy silnie są zabarwione osobistą dyspozycją psychologiczną autora i że przesadą byłoby je zbytnio uogólniać. Niemniej jednak jako symptom są znamienne. Każdy dzień, powtarzam, czyni wyłom w tradycyjnych pojęciach, uświęconych paroma tysiącami lat. Kwestie, o których dawniej nie mogło być mowy lub jeśli była mowa, to pod ilomaż osłonkami, wciskają się w literaturę. Teren, który zdawał się ściśle określony, zamknięty, odsłania nieznane przestrzenie i horyzonty; ileż tu

Zupełnie analogiczną dynamikę „wyższości-niższości” rozpoznaje w dzienniku Gombrowicz (op. cit., s. 157), w 1954 roku pisze tak: „Korespondencja Gide’a z Claudelem - cóż za teatrzyk! Jak to spokraczniało w ciągu paru lat! Nie śmieszy dialog wierzącego $\mathrm{z}$ niewierzącym, ale fraczek... ten fraczek doskonale francuskiej mondalité, to, że wszystko tak literacko wygładzone. Maja naga i Maja ubrana, Bóg pomiędzy Monsieur Gide i Monsieur Claudel. [...] Quelle délicatesse des sentiments! Właściwym autorem tej korespondencji jest służba domowa [...]. Gdyż cała ta delikatność wycackana jest i wychuchana przez ludzi niższych, ten wysoki dialog korzeniami tkwi w gminie - ale już zapomniał o swoich korzeniach i panoszy się, jakby istniał własnym życiem. Znów więc objawia się konieczność nawiązania do tej niższej prawdy, która jest u podstawy prawdy wyższej”.

33 Zob. W. Ś mi i j a, Literatura, której nie ma. Szkice o polskiej „literaturze homoseksualnej”. Kraków 2010, s. 97-110.

34 T. Że leń ski (B oy), Przedwiośnie? „Kurier Poranny” 1927, nr 51. Przedruk w: Felietony. 1. Oprac. W. Kopaliński. Objaśn. J. Szpotański. Warszawa 1958, s. 190. 
miejsca dla nowych kombinacji, odcieni. I życie staje się z każdym dniem śmielsze, wychodzą niby spod ziemi uczucia, symptomy, których „umowa społeczna” kazała wprzód nie widzieć ${ }^{35}$.

Ciekawym i zdecydowanie mniej znanym świadectwem recepcyjnym jest korespondencja Iwaszkiewicza. Dowiadujemy się z niej, że Korydona poznał dzięki Szymanowskiemu bardzo szybko - w roku publikacji, ale, zdaje się, nie przypadł mu do gustu, podobnie jak wcześniejsi Fałszerze. W liście Iwaszkiewicza do żony z 1 X 1924 czytamy:

Dostałem od Karola parę książek, między innymi Plain-Chant Cocteau, [...] ostatnio wydaną książkę Gide’a Corydon, dialogi o homoseksualizmie, która to książka jest skandalem literackim we Francji, przemilczana jest przez prasę i nawet nie ma jej ogłoszeń! Gide, zawsze pastor, i tę kwestię traktuje po pastorsku, chce znaleźć jakąś etykę tutaj i wyidealizować coś, co jest ostatecznie takim samym zjawiskiem życiowym, jak każde inne ${ }^{36}$.

Ciekawa wydaje się ta postawa Iwaszkiewicza, który z jednej strony skarży się na zmowę milczenia w Polsce (3 lata przed felietonem Boya) wokół Korydona, z drugiej, wyraża dezaprobatę wobec stosunku, jaki do zagadnienia homoseksualności ma Gide, a na koniec próbuje przedstawić swoje rozumienie zjawiska „poza dobrem i złem”, co chyba jednak, biorąc pod uwage jego twórczość z tamtego czasu, nie za bardzo jest szczere.

Kwestia Korydona wraca w korespondencji Iwaszkiewicza z młodziutkim Hertzem. Ten ostatni w liście z 2 VIII $1934^{37}$ przyznaje się, że czyta Fałszerzy po raz czwarty, natomiast o tym, że ze zdobyciem Korydona ma niejaki problem, mówi w liście z 8 XII 1934:

Moja lektura jest bardzo odpowiednia do mojego stanu [we wcześniejszych akapitach Hertz zdradza smutek, żal, pisze, że męczy go zima, że potrzebuje bliskości Iwaszkiewicza - W. Ś.]. Zdobyłem Corydona, po niemiecku oczywiście, i czytam już od tygodnia. Chciało mi się zacytować parę fragmentów, ale znowu dostanę taki list, jak wtedy, kiedy do Ciebie tak pięknie napisałem. Wracając do Gide'a, to Corydon jest słuszny w założeniu. Powinno to być koniecznie przełożone na polski. Uważam, że to dla Ciebie doskonale się nadaje i że Ty byś to pięknie przełoży ${ }^{38}$.

Zobaczmy, iż Hertz - zupełnie jak Józio Łohoyski - chciałby posłużyć się językiem, którego Korydon mu użycza, a przed którym Iwaszkiewicz się broni. Można przypuszczać, że ten język wydaje mu się na tyle użyteczny, że chciałby jego upowszechnienia - przekład na polski traktuje on wręcz jako konieczność.

W późniejszym o kilka dni liście, z 12 XII, Hertz wraca do Gide’a - jego utwór nie tylko stanowi punkt odniesienia $\mathrm{w}$ przedstawieniu sytuacji egzystencjalnej młodzieńca i starszego pisarza, ale wpływa na młodego Hertza, pozwala mu uwierzyć w siebie oraz skonfrontować się $\mathrm{z}$ własnym ojcem, a nawet skonstruować swoją podmiotowość:

Z powrotem wracam do tej nienawiści, o której piszesz: słuszna paralela z Gide’em; mam wraże-

A. i J. I wa s zki ew i czowi e, Listy 1922-1926. Oprac. M. B oj a now ska, E. Cie śla k. Wstęp

T. Burek. Warszawa 1998, s. 149-150.

37 P. Hertz, A. i J. Iwaszkiewiczowie, Korespondencja. T. 1: 1934-1948. Przepisali, oprac.

A. i R. Pa pi e s cy. Warszawa 2015, s. 27.

38

Ibidem, s. 41. 
nie, że Twoje (może raczej: nasze) upodobania homoseksualne kłują oczy niejednemu mieszczuchowi. Tzw. opinia jest tym samym źle wobec Ciebie nastawiona. $Z$ drugiej strony, nigdy bym nie wyrzekł się tzw. zboczenia. Pomyśl, ile to daje szlachetnych wrażeń, często głębokich bardzo wzruszeń i przeżyć. Zauważ, że ludzie pobłogosławieni przez naturę owym „przewrotnym pociagiem erotycznym”, jak mówi o tym Freud, są inni, bardziej subtelni i szlachetni, jednym słowem: ciekawsi od zwykłych ludzi.

Zabawne, że〈bym〉 to ja w liście do Ciebie, polskiego nieomal Wilde’a, pisał tę krótka apologię homoseksualizmu, jest to wyraźny wpływ Corydona. Aha, wyobraź sobie, że miałem długa rozmowę z moim ojcem, w wyniku której uregulowane zostały stosunki domowe: są one teraz zupełnie poprawne i chłodne ${ }^{39}$.

Niemal rok później, 15 XI 1935, Hertz otrzymuje informację, że przygotowywany jest przekład Korydona. Martwi się o jakość tego przedsięwzięcia, ale cieszy się, iż książka się ukaże na rynku wydawniczym:

Dowiedziałem sie, że Corydon wyjdzie po polsku u Przeworskiego. Tłumaczy to młody Izraelita, prawnik, dość kulturalny, nie wiem, czy comme ça, nazwiska nie pamiętam. W każdym razie przyjemnie, że to wyjdzie u nas ${ }^{40}$.

Iwaszkiewicz był wielkim admiratorem zaginionej powieści Szymanowskiego zatytułowanej Efebos. Niestety, spłonęła ona w mieszkaniu Iwaszkiewicza w 1939 roku. Jakkolwiek była dla Szymanowskiego ważna, to nie mogła wyjść drukiem za jego życia, ani po jego śmierci - nie życzyła sobie tego matka kompozytora. Pod koniec jego ziemskich dni Janta-Połczyński odbył z nim rozmowę, podczas której go pyta o Efebosa:

- Co o niej myślisz dzisiaj, Karolu?

- Jest gdzieś na dnie szuflady czy kufra. Pewnie jest to tam coś warte, ale wart na pewno jest tylko jeden rozdział, jeden dialog, dialog o miłości. Zdaje się, że powiedziałem tam wiele, być może wszystko, co miałem do powiedzenia w najważniejszej, najpiękniejszej dla mnie sprawie... ${ }^{41}$

Natomiast Iwaszkiewicz w Spotkaniach z Szymanowskim ocenia powieść niezwykle dobrze i sytuuje ją w tradycji wysokiego homoseksualnego modernizmu, gdzie Pater, Proust i właśnie Gide. Ten ostatni wydaje się szczególnie ważną postacią ze względu na kluczowy fragment Efebosa, który jest niczym innym, jak właśnie neoplatońskim dialogiem uwznioślającym homoerotyzm - w bardzo korydonowskim duchu:

Gdybyśmy mogli studiować teraz Efebosa, ujrzelibyśmy zadziwiającą zbieżność jego postaw filozoficznych i artystycznych z tym, co dawały owoczesne prądy umysłowe Francji, niezależna - jak mówiłem już - zbieżność z Proustem i Gide'em, świadczącą o tym, że Szymanowski był nieodrodnym synem Europy i że pozostawiony sam sobie szedł drogą tą samą, co wielcy moraliści Zachodu. Ta równoległość myśli Szymanowskiego do tego, co było ostatnim wydźwiękiem XIX wieku, świadczy o niezaprzeczonej oryginalności jego umysłu, a pośrednio jest świadectwem jego wielkości jako artysty i jako człowieka ${ }^{42}$.

Efebosa, poza dwoma fragmentami, w tym rozdziału zatytułowanego Sympozjon, znamy jedynie $z$ omówienia Iwaszkiewicza. O tyle więc, o ile wolno nam wyciagać wnioski, powieść Szymanowskiego istotnie była „wydźwiękiem XIX wieku” i mogła

Ibidem, s. 43-44. Podkreśl. W. Ś.

Ibidem, s. 72 .

J a n t a, op. cit., s. 38 .

J. I w a s z ki ew i c z, Spotkania z Szymanowskim. Kraków 1947, s. 96. 
być, gdyby się, oczywiście, ukazała, polskim Korydonem, mogła - wrócę do metafory Eribona - psychiatrom przeciwstawić Greków, gdyż „Powieść Szymanowskiego, zaczęta pół żartem pół serio, stopniowo coraz bardziej go absorbowała, robota go wciaggała i im dłużej ją pisał, tym bardziej się do niej przywiązywał [...]”33.

Pisanie [...] Efebosa nie było przypadkowym wypełnianiem luki czasu przez nudzącego się w elizawetgradzkiej samotni kompozytora - wypływało ono z głębokiej wewnętrznej potrzeby i rozwiązywało Szymanowskiemu pewne zagadnienia, które go od dawna męczyły, a doszły do uświadomienia przez kompletną izolację od świata zewnętrznego ${ }^{44}$.

Korydon stanowi dyskursywną apologię homoseksualizmu/pederastii, ale inspiracja, jakiej polskim twórcom Gide dostarcza, nie ogranicza się tylko do tego utworu. W nieco bardziej subtelny, a nawet przewrotny, sposób takiej inspiracji dostarczały słynne powieści Gide’a - Fałszerze i Immoralista. W innym miejscu omawiałem debiutancką powieść Andrzejewskiego - Ład serca, jako swego rodzaju anty-Immoralistę ${ }^{45}$, liczne ekwiwalencje między tymi tekstami pozwalają odczytywać utwór Andrzejewskiego jako odwracające logikę pierwowzoru przedstawienie motywowanego religijnie wyparcia pożądania homoseksualnego, co współbrzmi z biograficznymi perypetiami samego pisarza, który, zniszczywszy swoją debiutancką i (najprawdopodobniej) homoerotyczną Noc, a także wyrzekłszy się własnego homoseksualizmu (zakończenie związku z Eugeniuszem Biernackim), stał się (na krótko) katolickim neofitą.

Polski przekład Fałszerzy pióra Jarosława Iwaszkiewicza i Heleny Iwaszkiewiczówny pojawił się bardzo szybko - w 1927 roku. Jakkolwiek Iwaszkiewicz w listach wyrażał się o nim krytycznie, to w recenzji zamieszczonej w „Wiadomościach Literackich" wychwalał powieść autora Pokarmów ziemskich ${ }^{46}$. Praca nad nią nie była bez wpływu na jego własną twórczość. Najdobitniejszym tego przykładem jest powstałe w 1929 roku, ale opublikowane dopiero w 1971 roku opowiadanie Przyjaciele:

Opowiadanie Przyjaciele napisałem w roku 1929, to znaczy już po zaczęciu, a przed skończeniem Brzeziny. Zostało zapowiedziane w wydawnictwie razem z Brzezina właśnie. Potem opowiadanie to zostało przeze mnie wycofane, a na jego miejsce przyszły Panny z Wilka.

- mówi we wstępie do niego autor [I 7] ${ }^{47}$. Według Hertza powołującego się na ten

Ibidem, s. 87.

Ibidem, s. 86. B. D ą b row s ki (Szymanowski. Muzyka jako autobiografia. Gdańsk 2010, s. 133) w swojej monografii zauważa, że północnoafrykańska podróż Szymanowskiego w marcu 1914 a także wyjazdy do Italii i na Sycylię - była niejako podróżą imitującą wcześniejsze wojaże Wilde’a i Gide’a (a kto wie, czy i nie W. van Gloedena): „jeśli wierzyć lirykom napisanym przez Szymanowskiego po francusku [...], w których pojawiają się arabscy chłopcy - podobnie jak w przypadku Gide’a i Wilde’a była czymś więcej niż zwykłą turystyką”.

Śm i j a, Homoseksualność i polska nowoczesność, s. 267-272. W przyjętym właśnie do druku tekście Notatki do autobiografii. Przyczynek do biografii. Jerzy Andrzejewski-dzieło (i życie) otwarte (,Teksty Drugie”) wskazuję na związki poetyki biografizmu u Andrzejewskiego i Gide’a.

Ele u t e r, Nowa powieść Andrzeja Gide’a. „Wiadomości Literackie” 1926, nr 14, z 4 IV, s. 2.

Skrótem I odsyłam do: J. I wa szki ew i c z, Przyjaciele. W: Opowiadania muzyczne. Warszawa 1971. Ponadto stosuje jeszcze takie skróty: G = A. Gi d e, Fałszerze. W: Fałszerze. Przeł. H. I w a s zkiewiczówna, J. Iwaszkiewicz; Dziennik „Fałszerzy”. Przeł. J. Rogoziński. Oprac. [całość] K. J a r o s z. Wrocław 2003. BN I 251. - J = K. J a r o s z, wstęp w: Fałszerze. - Dziennik „Fatszerzy”. Liczby arabskie i rzymskie (w przypadku wstępu Jarosza) oznaczają stronice. 
sam wstęp (po latach pisarz przyznaje: „w owoczesnej Warszawie zbyt łatwo można było odczytać wzorce opowieści [...]” 〈I 7 7 ) wstrzymanie druku opowiadania spowodowane było możliwością wybuchu skandalu obyczajowego, Hertz zwraca uwagę na zbieżność losów głównego bohatera „Z samobójczą śmiercią jego teścia, Stanisława Lilpopa, z niemiecka brzmiące nazwisko głównej postaci, Wiesława Wolffa, nasuwające myśl o zaprzyjaźnionym z Karolem Szymanowskim, bogatym amatorze muzyki, Stefanie Spiessie, a także rzadkie imię młodego arystokraty, Achillesa Koreckiego, które łatwo byłoby wtedy kojarzyć z obracającym się w kręgach artystycznych Warszawy Achillesem Breza, pochodzącym z wielkopolskiej rodziny ziemskiej" ${ }^{48}$.

Stefan Spiess nie tylko ma niemiecko brzmiące nazwisko - Wolff - ale jest także, podobnie jak bohater opowiadania, właścicielem fabryki chemicznej. Należałoby też przypuszczać, iż postać Achillesa Koreckiego, drugiego z protagonistów, jest inspirowana (również?) Zbigniewem Uniłowskim, późniejszym autorem Wspólnego pokoju, który od roku 1925 utrzymywał bliskie kontakty ze Spiessem i był przez niego finansowany. Trzeba przy tym wspomnieć, że opowiadanie, ostatecznie opublikowane w 40 lat po napisaniu (i niedługo po śmierci Spiessa w 1968 r.), wyszło drukiem w zbiorze Opowiadań muzycznych. Choć na poziomie treści trudno odnaleźć bezpośrednie związki z muzyką (wiemy, że Wolff spędzał czas „grając na fortepianie stare etiudy" 〈I 12〉), to taka rama edytorska zdaje się stanowić wskazówkę uprawdopodobniającą tę interpretację biograficzną.

Mówiąc o Przyjaciołach, musimy mieć na uwadze nie tylko kontekst zbioru opowiadań z 1932 roku, w którego skład opowiadanie nie weszło, i ten, w którego ramach w końcu się pojawiło w 1971 roku, lecz też inny kontekst, w jaki utwór się wikła - nie napisanej powieści homoseksualnej Iwaszkiewicza, czyli Zmowy mężczyzn. Powinowactwa, o których należy tu wspomnieć, są liczne i występują między Przyjaciótmi a Zmowa nie tylko na poziomie formy, ale także treści. Chyba warto się zastanowić, czy Przyjaciele nie stanowią rozwinięcia (i transpozycji) usuniętego ze Zmowy mężczyzn wątku homoseksualnego ${ }^{49}$ (dalszą oznaką jego pominięcia byłaby zamiana Przyjaciót na Panny z Wilka ${ }^{50}$ ), bo ostatecznie wycofane opowiadanie nie maskuje - w przeciwieństwie do robiących to (przynajmniej częściowo) Panien z Wil$k a^{51}$ - pożądania homoseksualnego, kluczowego dla rozwoju fabuły watku. Badacze twórczości Iwaszkiewicza Zmowę mężczyzn chyba nieco bagatelizują, być może niesłusznie, utwór jest bowiem świadectwem ważnej przemiany w stylu prozy pisarza. Do czasu Zmowy mężczyzn swój styl Iwaszkiewicz określa jako „barokowy”, za jego zaś apogeum uznaje Pejzaże sentymentalne, po których postanawia $z$ tym stylem definitywnie zerwać. Iwaszkiewicza wczesny sposób pisania (np. Ritz uznaje

Portret młodego artysty. Listy Józefa Rajnfelda do Jarosława Iwaszkiewicza 1928-1938. Wyd. z notami adresata P. Hertz. Red. M. Za gań c zy k. Warszawa 1997, s. 50, przypis.

Zob. Ś mi ej a, Literatura, której nie ma, s. 37-60.

Toponim „Wilko” może wiązać oba opowiadania, wszak pochodzi od słowa wilk (niem. der Wolf). Tajemnicza żona Wolffa, o której dowiadujemy się jedynie, że zmarła, nosi imię tożsame $z$ imieniem Kazi - najbliższej Rubenowi spośród żyjących wilkowskich panien (ale też najmniej kobiecej).

Zob. B. Zi eli ń s k a, Mroczne ścieżki pożadania. Interpretacja psychoanalityczna. W zb.: „Panny z Wilka" Jarosława Iwaszkiewicza. Red. I. I wa si ów, J. Ma dej ski. Szczecin 1996. - Ritz, op. cit. 
w nim funkcję sublimacji ${ }^{52}$ ) doczekał się szeregu omówień, a nawet monografii ${ }^{53}$. Utwory powstałe pod koniec lat dwudziestych: Zmowa mężczyzn i Przyjaciele, stanowią eksperymentalne intermezzo w rozwoju Iwaszkiewiczowskiego stylu, dopiero po nich narodzi się Iwaszkiewicz - wielki realista i psychologista. „Nowa prostota” (użyjmy terminu Ritza) ${ }^{54}$, w przeciwieństwie do okresu wczesnego, jak i późnego jego twórczości, nie doczekała się żadnego szerszego omówienia.

Zmowa mężczyzn wykorzystuje chwyty i rekwizyty powieści popularnej (nagłe, niespodziewane i dramatyczne zwroty akcji, powikłania miłosne, umieszczenie bohaterów w wyższych sferach), choć nie „ześlizguje się" w melodramatyczność, a tytułowy temat „Zmowy mężczyzn”, problem artysty/wyrobnika (Tadzio) czy iluminacji religijnej (ksiądz Kurek) sytuują ten utwór blisko powieści psychologicznej, ostatni $z$ wątków zbliża ją nawet do zagadnień związanych ze współczesną francuską myślą religijną (J. Maritain, F. Mauriac). W Zmowie mężczyzn akcja toczy się wartko, jak na romans przystało, unika Iwaszkiewicz opisów, a sensy psychologiczne podane sa poprzez suche wyliczanie faktów i relacjonowanie rozmów, co zreszta sprawia mu najwięcej trudności (list do żony z 5 III 1926) ${ }^{55}$. Ta sucha relacyjność w niektórych rozdziałach Zmowy mężczyzn przechodzi w dialogiczność, narrator się wycofuje, my zaś słuchamy niezapośredniczonych rozmów bohaterów (np. obszerne fragmenty rozdziałów XVI i XIX). Taki eksperymentalny sposób prowadzenia fabuły utworu zdominował także Przyjaciót: opowiadanie jest, w stosunku do Zmowy mężczyzn, „zradykalizowane”, adres czytelniczy tego opowiadania wydaje się węższy, choć podwojony ${ }^{56}$, pojawia się wyparta ze Zmowy mężczyzn homoseksualność ustanowiona jako motor fabuły ${ }^{57}$ i silnie $z$ nią związane zagadnienie wzajemnego odniesienia życia oraz sztuki. Ascetyzm narracji widoczny w pewnych partiach Zmowy mężczyzn w Przyjaciołach osiaga granice, których nigdy później już Iwaszkiewicz nie przekroczy. Opowiadanie zostaje pozbawione wszelkich chwytów literatury popularnej: szybkiej akcji, standardowej romansowości etc. Ritz powie o nim, że jest „swego rodzaju protokołem z rozmowy" ${ }^{58}$. Sam Iwaszkiewicz pisał natomiast tak:

Myślę, że tych czterdzieści lat przebywania w ukryciu wyszło noweli na dobre. A przede wszystkim, po wszystkich próbach nowoczesnych nie będzie raziła jej forma, która jest jakimś dziwnym przeczuciem Ivy Compton-Burnett ${ }^{59}$ i która bardzo raziła tych paru ludzi, którzy Przyjaciót w swoim czasie czytali, zresztą bez wielkiego entuzjazmu. [I 7]

G. Ritz, Jarosław Iwaszkiewicz. Pogranicza nowoczesności. Przeł. A. K o p a c ki. Kraków 1999, s. 151.

Zob. M. J ę d ry c h ow s k a, Wczesna proza Jarosława Iwaszkiewicza. Wrocław 1977.

Rit z, Jarosław Iwaszkiewicz, s. 151.

Iw a s zki ewiczowie, op. cit., s. 469.

O podwojonych adresach czytelniczych dotyczących homoerotycznych tekstów Iwaszkiewicza pisałem w szkicu Kanon i kanony, czyli jak rozumieć pojęcie literatura homoseksualna (w: Literatura, której nie ma).

A nawet nie sama homoseksualność, co kryzys defninicyjny, jaki to pojęcie wywołuje w języku. Szerzej o tym kryzysie piszą B. Warkocki i T. Kalis ściak w szkicu Czesław Miłość (w zb.: Warszawa Miłosza. Red. M. Zal e ski. Warszawa 2013).

Rit z, Jarosław Iwaszkiewicz, s. 114.

O pisarstwie I. Compton-Burnett zob. B. B a ł u t o w a, Nowe formy powieści. Twórczość Ivy Compton-Burnett. Wrocław 1975. 
Ich forma „prorocza” - wedle słów samego Iwaszkiewicza - jest, także jego zdaniem, „dziecinnie [...] ułomna”, określa ją nawet jako „bezkształtne gruzła formy”, mówi o „zasadniczym zgrzycie kompozycyjnym, kontraście pomiędzy nowocześnie pomyślaną osobowością Achillesa a Wiesławem Wolffem, który w całości należy do literatury minionej epoki [...]" (I 8). Ze wszystkimi autokrytycznymi komentarzami Iwaszkiewicza zgadza się przywoływany Ritz, stwierdzający, że w efekcie „Przyjaciele to jednak utwór w jego twórczości marginalny"60.

Owszem, Przyjaciele nie są opowiadaniem należącym do Iwaszkiewiczowskiego kanonu, a krytyczna i czytelnicza recepcja tego tekstu wydaje się znikoma. Ale, moim zdaniem, utwór stanowi jeden $z$ kluczy niezbędnych do zrozumienia drogi artystycznej autora Zmowy mężczyzn, umożliwia analizę wewnętrznych mechanizmów rozwoju jego prozy. Sam fakt wpisania/wypisania go z kontekstu Brzeziny i Panien $z$ Wilka powinien wszystkim mówiącym o jego marginalności dać wiele do myślenia.

Warunki i możliwości wypowiadania homoseksualności stanowią jeden z zasadniczych problemów formalnych, z jakimi boryka się Iwaszkiewicz w całej swojej twórczości, szczególnie jednak na przełomie lat dwudziestych i trzydziestych, kiedy artysta rezygnuje $z$ „sublimacji i estetyzacji oraz zachowania wierności stylowi młodopolskiemu” na rzecz „poniekąd oświeceniowej próby bezpośredniej tematy-

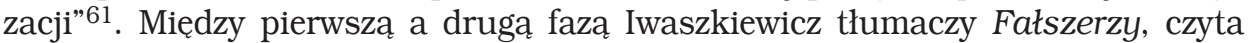
Korydona, pisze Przyjaciót.

Rekonstruowanie erotycznych i literackich skandali międzywojennej Warszawy, a więc szukanie środowiskowego klucza, byłoby dość jałowa procedura. Zamiast tego chciałbym poddać głębszej refleksji gide'owską inspiracje pojawiająca się w Przyjaciołach, gdyż stanowi ona, moim zdaniem, katalizator, który umożliwił Iwaszkiewiczowi artystyczne i płodne literacko wpisanie tematyki homoerotycznej w splot nowych zagadnień estetycznych, społecznych, kulturalnych i ekonomicznych, z jakimi boryka się polskie społeczeństwo u progu Wielkiego Kryzysu.

$\mathrm{Na}$ rolę literatury, i to przede wszystkim francuskiej, jako inspiratorki akcji opowiadania naprowadza nas autor na samym początku - pierwsza scena toczy się w księgarni Gebethnera i Wolffa przy dziale $z$ literatura francuską, a Wiesław Wolff $\mathrm{z}$ księdzem Gallienim (opiekunem drugiego z protagonistów - młodego Achillesa Koreckiego) „Mówią o książkach ze swobodą ludzi bardzo oczytanych” (I 11). Literackość Przyjaciół sygnalizowana jest w jednym $z$ dialogów, jaki Wolff prowadzi ze swą powierniczką, panią Janiszewską:

- Jesteś śmieszną powieściową postacią - powiedziała pani Janiszewska ze zgorszeniem. - Któż widział tak na serio brać literaturę?

Wolff przyznał rację pani Janiszewskiej.

- No, ale trudno; czasami i ludzie z literatury muszą ożywać. [I 14; podkreśl. W. Ś.]

Później, w którejś z pierwszych rozmów Wolffa z Koreckim, przewija się nazwisko Gide’a. Jedno z kluczowych pytań, jakie stawiają sobie bohaterowie, dotyczy kwestii relacji między literaturą a życiem: 
- Co wy wszys cy z tą literaturą... Niedawno pani Janiszewska, a teraz ten chłopak. Czy ty wiesz, co ważniejsze? Czy życie, czy literatura? [I 28; podkreśl. W. Ś.]

Czy literatura może mówić prawdę? Na jakich warunkach jest referencyjna, w jakim zaś stopniu deformuje, a nawet kreuje fakty życiowe? Jakie sa jej ograniczenia poznawcze? Pytania te powracają w opowieści uparcie - czasem pozornie bez związku (np. w inicjalnej rozmowie o zafałszowanych pamiętnikach Poincarégo $\langle\mathrm{I} 10\rangle$ ), ale w istocie stanowią jedną $\mathrm{z}$ najważniejszych osi tematycznych opowiadania: kwestia literatury/życia pojawia się w rozmowie o samobójstwie (I 27-28), podtrzymuje ją w całym niemal utworze wspólna i symultaniczna lektura Iliady, która co innego znaczy dla Achillesa, co innego zaś dla Wolffa.

Problem literackiej mimesis został w rewolucyjny sposób podniesiony przez Gide'a w Fałszerzach, w których - wiernie tu za nimi postępują Przyjaciele - splata się z próbą wyrażenia pragnienia homoerotycznego i kwestią umownie nazwana ekonomiczną. Jak zwięźle oddał to Krzysztof Jarosz:

pojęcie fałszerstwa jest dla niego [tj. Gide’a] dużo bardziej pojemne i pojmowane w sposób przenośny dla zdiagnozowania zarówno współczesnych mu, jak i uniwersalnych postaw ludzkich. Tak rozumiana kategoria fałszerstwa, fałszu, fałszywości i zakłamania, przeciwstawna szczerości i autentyczności, stanowi tematyczny zwornik powieści [...]. [J LIX-LX]

W jednym $z$ kluczowych fragmentów Fałszerzy Edward (jako porte-parole Gide’a) stwierdza w rozmowie z panią Sofroniską: „To, co chciałbym stworzyć, byłoby czymś w rodzaju Kunst der Fuge. I nie widzę powodu, aby to, co było możliwe w muzyce, było nie do stworzenia w literaturze...” (G 191). Muzyczna powieść Edwarda nosi tytuł tożsamy z powieścią Gide’a Fałszerze. Interlokutorzy Edwarda Sofroniska, Laura Vedel i Bernard Profitendieu - okazują się sceptyczni wobec pomysłu pisarza:

[...] Sofroniska odpowiedziała, że muzyka jest sztuką matematyczną [...].

Po czym - dodała Laura - świat był na długo uleczony z fugi. Uczucie ludzkie, nie mogąc się już w niej zmieścić, poszukało innych mieszkań. [G 192]

Bernard natomiast dopytuje się o to, kim są owi tytułowi fałszerze (G 192). Edward rozczarowuje rozmówców swoją odpowiedzią - twierdzi, że sam nie wie, ale „myśli z dziedziny wymiany pieniędzy, dewaloryzacji, inflacji po trochu opanowywały jego książkę [...]”, a potem przytacza historię fałszywej 10-frankówki, która warta jest w rzeczywistości 2 su, lecz „Będzie warta dziesięć franków aż do chwili, do której nikt nie rozpozna, że jest fałszywa” (G 193).

Znamienne, iż we wpisie $z$ dziennika Edwarda następującym po tym fragmencie autor dezawuuje znaczenie własnych uwag: „Sofroniska, Bernard i Laura pytali mnie dzisiaj o moją powieść. Po cóż się dałem wciągnąć w tę rozmowę? Mówiłem same głupstwa” (G 194). Czytelnik Fałszerzy pozbawiony spójnej instancji narracyjnej, która zapewniałaby równie spójną interpretację świata powieściowego, gubi się nie wiedząc, czy Edward rzeczywiście wykłada swoją teorię powieści, czy też „Mówi [...] głupstwa”.

Iwaszkiewicz, jak postaram się to udowodnić, umieszcza Przyjaciół w zbiorze opowiadań muzycznych nie tylko ze względu na pierwowzór głównego bohatera, ale przede wszystkim dlatego, że zaczerpnięty od Gide’a pomysł literackiej fugi bardzo 
przypadł mu do gustu, problem zaś fałszerstwa, przepływu pieniędzy, fałszywego głosu, a co za tym idzie - kwestie niedostępności prawdy, zaniku instancji nadających sens, pesymizm poznawczy stanowią, jak już napomykałem, jedno z głównych zagadnień opowiadania Iwaszkiewicza. Gide’owska inspiracja, którą chcę się tu zająć, ma zatem dwa uzupełniające się i kumulujące się w ideową całość tryby. Pierwszy to tryb formalny - muzyczny. Drugi to tryb tematyczny: uważna, translatorska lektura Gide’a pozwala Iwaszkiewiczowi ująć w literacką formę rzeczywiste postaci, ich motywacje, psychologie, postawy, relacje. Gide niejako legitymizuje inne niż sublimacyjne (charakterystyczne dla wcześniejszych utworów Iwaszkiewicza, takich jak Zenobia Palmura) pisanie o homoseksualności w jej uwikłaniu w problemy współczesnego świata, polityki, sztuki, ekonomii etc. Krótko mówiąc, Iwaszkiewicz, który jest uznawany za autora wchodzącego w dialog z wielkimi europejskimi prozaikami: Lwem Tołstojem, Thomasem Mannem, Marcelem Proustem, bardzo intensywnie dialoguje również z Gide'em. Lektura Fałszerzy nie tylko pozwoliła mu odnowić język własnej prozy, ale także postawiła przed nim głębsze, filozoficzne problemy ontologii twórczości, mimesis, psychologizmu - a więc zagadnienia, z którymi autor Przyjaciót mierzy się w swoich najwybitniejszych dziełach $z$ lat trzydziestych.

Opowiadanie składa się z 20 krótkich rozdziałów, pierwsze dwa mają charakter „didaskaliów”, zawiązują akcję, wprowadzają obu bohaterów: niedoszłego maturzystę, nowoczesnego Achillesa Koreckiego, jego starszego przyjaciela Wiesława Wolffa, bogatego fabrykanta i estetę; kształtują miejsce akcji, postaci poboczne, etc; kolejne rozdziały „protokołuja” dialogi, narrator się wycofuje, a według Ritza: „Opowiadanie do końca odmawia empatycznego wejrzenia w serce swojego tragicznego bohatera" 62 . Wiesław Wolff spotyka Achillesa w księgarni, potem zaś zupełnie przypadkowo na przyjęciu weselnym (gdzie równie nieoczekiwanie się znalazł). Zabiera $z$ sobą chłopca do restauracji Bristolu, gdzie dowiaduje się o nim nieco więcej. Achilles jest synem kresowych ziemian, który nie zdał matury i musi przebywać w Warszawie do czasu poprawek. Potem spotykają się oni ze sobą dość często. Ich rozmowy, w których problemy prywatne i kwestie ogólne dotyczące stanu kultury czy społeczeństwa nieustannie się przeplatają, stanowią kanwę opowiadania. Jedną $z$ naczelnych kwestii poruszanych przez nich jest samobójstwo.

Młody Korecki potrzebuje pieniędzy i wyzwolenia z więzów rodzinnych. Pierwszą rzecz może mu zapewnić „romans” z Wolffem (krąży na jego temat plotka homoseksualna), drugą - różne planowane przez chłopca „ucieczki”, jak choćby praca w fabryce, o której rzekomo marzy. W trakcie opowiadania okazuje się, że Achilles mieszka z Rawita, młoda podrzędną aktoreczką, będącą utrzymanką adwokata Wolffa. Gdy adwokat ja porzuca, Rawita potrzebuje kilku tysięcy złotych na spłacenie swoich długów. Choć Achilles zamierza wydobyć pieniądze od Wolffa, jego prawdomówność i wierność wobec Rawity wydają się przynajmniej równie wątpliwe, jak jego intencje wobec Wolffa („Jadzia nie jest człowiekiem” - powie nawet 〈I 103〉). Kiedy dostaje już upragniony czek - jego wypisanie nie stanowi żadnego kłopotu dla posiadacza ogromnej fortuny - siada obok Wolffa na kanapie i całuje go w usta 
oferując tym samym płatną miłość homoseksualną. Wolff jednak odrzuca go gwałtownie „Pomyliłeś się, mówi (I 116). Monetaryzacja relacji obnaża prawdę, a właściwie chyba brak prawdy, brak istoty, brak punktu oparcia w świecie - Wolff pisze długi list pożegnalny, następnie zaś zabija się strzałem w żebro (kula przeszywa najprawdopodobniej serce), swoim spadkobierca czyniąc Achillesa. Gdy ten przybywa do willi Wolffa, patrzy na trupa i reprodukcje portretu Damy z łasiczka Leonarda da Vinci zwana „fałszywą Madonną. Podczas rozmowy z robotnikiem pracującym w willi dowiaduje się, że Wolff miał się żenić z panną Kazią. Nie mogąc dłużej patrzeć na Damę z łasiczka, Achilles niszczy reprodukcję - „Podarte kawałki damy z gronostajem bieliły się na trotuarze, pod oskubanym drzewkiem” (I 136). $\mathrm{W}$ ostatnim, pośmiertnym, fragmencie Achilles rozmawia z księdzem Gallienim, swoim korepetytorem, który tłumaczy mu, iż umiłowane przez Wolffa piękno stało się zabójczym „kręgiem nicości” (I 137), Achilles zaś zwierza się księdzu, że czegoś chce, ale nie umie tego nazwać, „a boi się fałszywego imienia, bo może go zabić, jak jego [tj. Wolffa] zabiło..." (I 141).

Prześledźmy pokrótce, jak w konstruowaniu tej lapidarnie tu zreferowanej historii spożytkowuje Iwaszkiewicz pomysły autora Fałszerzy ${ }^{63}$. W tym celu sięgnijmy po recenzję Eleutera $z$ „Wiadomości Literackich”, w której zdaje on sprawozdanie ze swojej lektury powieści Gide’a. Na co zwraca uwagę Iwaszkiewicz-Eleuter? Po pierwsze - jego spojrzenie koncentruje się na nowatorskiej formie powieściowej:

Co się tyczy natury artystycznej książki, nasuwają się tu przede wszystkim kwestie formalne, które sam Gide wielokrotnie przez usta pisarza Edwarda roztrząsa. Mimo pozornej niechlujności budowy [...] - jasne jest, że konstrukcja tej powieści zajmowała ważne miejsce w ogólnych pomysłach architektonicznych Gide'a ${ }^{64}$.

W ramach tej formy szczególne zainteresowanie autora Przyjaciół budzi muzyczność formy Fałszerzy - Iwaszkiewicz przywołuje znany nam już cytat o literackiej sztuce fugi, a następnie komentuje go:

Trzeba przyznać, że tematy swych fug obiera Gide frapujące, „wpadające w ucho”, że splata je i rozplata z prawdziwą nonszalancją, w której dopiero kryje się sucha i pewna siebie maestria ${ }^{65}$.

Iwaszkiewicz wydaje się szczerze zafascynowany nowymi muzycznymi możliwościami i idącą w parze $z$ nimi oszczędnością typowo językowych i literackich środków wyrazu:

Gide nie posiada barwy, ani plastyki, nie jest malarzem, ale czysty i pewny rysunek przedstawia nam to, czego chce autor, z niebywałą ścisłością i dokładnością. Suchość i oszczędność zdania, umiarkowanie słownictwa są mu w tym pomocą. Doskonałe w rysunku tematy, którymi operuje na sposób muzyczny, sprawiają, że sztuka jego opanowuje czytelnika. Pozwala mu przebrnąc z zamkniętymi oczami przez bagna, gadatliwość, czasami nawet naiwność66.

Przyjaciele są Iwaszkiewiczowską próbą zrealizowania fugi z jej matematyczną

W pewnym sensie już gramatyczna forma tytułu - liczebnik zbiorowy w rodzaju męskoosobowym, w mianowniku, może stanowić wyznacznik tego związku tekstowego. 
ścisłością wyrażająca się w tym opowiadaniu choćby powściągliwością narracji i uproszczeniem języka utworu. Istotę fugi stanowi temat, dwa (przynajmniej) głosy i kontrapunkt. Gdy w jednym z głosów pojawia się temat, w pozostałych głosach pojawia się kontrapunkt. Temat rozbrzmiewa najpierw w postaci zasadniczej. Przejmuje go - jako odpowiedź - kolejny głos fugi. W tym czasie w głosie pierwszym melodia rozwija się nadal jako kontrapunkt do przejętego tematu. Następstwo tematu i odpowiedzi jest obligatoryjne. Konstrukcja opowiadania, w której dominuja dwa głosy - Achillesa i Wolffa - ułożone kontrapunktowo i przejmujące temat, wydaje się realizacją tych podstawowych założeń konstrukcyjnych fugi. Mówi Achilles:

Wszelkie zjawiska można podporządkować tym słowom, które ostatecznie nie to znaczą, co znaczą. Przez to, na przykład, mogłoby ci się wydawać, że wywierasz na mnie wpływ. Oczywiście, że jestem mniej silną indywidualnością. I przez to samo ja się poddałem tobie. Ale tylko w znaczeniu dobierania słów, w znaczeniu stworzenia sobie wspólnego języka, jaki się musi wytworzyć pomiędzy dwoma przyjaciółmi. Wybraliśmy twój język. [I 102]

Temat podejmuje zatem głos Wolffa, natomiast głos drugi - Koreckiego, jest ustawiony w kontrapunkcie. Co więcej jednak - fuga stanowi czystą konstrukcję muzyczną, niereferencyjną i nieprzedstawieniową, abstrakcyjną i czystą, co szczególnie dobrze widać w Bachowskiej Kunst der Fuge, stojącej na antypodach wszelkiej muzycznej programowości. I dokładnie taką funkcję pełni język Przyjaciót, język, w którym zanika wszelkie pozajęzykowe odniesienie -jego istnienie może być nawet groźne, zakłócać czystą konstrukcję fugi-dialogu:

- Przyszło mi do głowy... Przyszło mi do głowy, że...

- Dlaczego nie domawiasz?

- Że staję się trochę za szczery. Rozmowy nasze jak na rozmowy przyjacielskie grzeszyć zaczynają prawdziwościa.

- Męczysz mnie. Więc chcesz, abyśmy byli fałszywi...

- W tych dziedzinach, których nie potrafimy sobie nawzajem wytłumaczyć, powinniśmy być nieszczerzy. [I 100]

Trudno zatem zdefiniować w kategoriach dyskursywnych temat główny Przyjaciół. Miłość? Przyjaźń? Piękno? Homoerotyzm? Przemiany społeczne? Wszak zagadnienia te pojawiaja się $\mathrm{z}$ pewną powtarzalnością w fudze Iwaszkiewicza. Wydaje się jednak, że temat właściwy należy wygenerować jako powracający motyw melodyczny przenikający te wszystkie tematy cząstkowe - jest nim poczucie rozerwania związku między signifiés a signifiants, w konsekwencji zaś niemożność orzeczenia o prawdziwości/fałszywości czegokolwiek, to właśnie ów „krag nicości”, o którym mówił ksiądz Gallieni:

- Zawsze szydzisz.

- No, nie zawsze. Dziś rozmawiałem z Jadzią całkiem poważnie, ale potem wszystko poszło gładko. Zacząłem kłamać. Tylko nie wiem, w jakich punktach kłamałem. [I 114]

Ta sytuacja ma w świecie opowiadania bardzo poważne implikacje - obaj bohaterowie (Korecki i Wolff) marzą o ucieczce (słowo powraca wielokrotnie na kartach opowiadania - zob. np. I 51), a więc fudze, wszak fuga to właśnie ucieczka. Dla jednego jest to ucieczka $z$ domu rodzinnego, dla drugiego formę ucieczki - uskutecznioną - stanowi samobójstwo. 
Rozpoznanie kryzysu reprezentacji tak znakomicie przeprowadzone u Gide'a łącza interpretatorzy $\mathrm{z}$ kategoriami ekonomicznymi ${ }^{67}$ - zbiegło się $\mathrm{z}$ wycofaniem złotych monet będących zarazem znakiem pieniężnym i przedstawiających realną wartość szlachetnego kruszcu, z jakiego były sporządzone (J XC). Zdaniem polskiego badacza, idącego tu w ślad za Jeanem-Josephem Goux, Gide wyraża na płaszczyźnie literackiej przejście od społeczeństwa opartego na reprezentacji uważanej za wiarygodną, a więc takiego, w którym wartości są gwarantowane transcendentnym znaczeniem (ojciec, język, fallus) lub odsyłają do swych rzeczywistych desygnatów (złota moneta jest zarazem znakiem i desygnatem) do społeczności, w której nie istnieje wymienialność znaków (językowych i pieniężnych) na wartości (transcendentny sens i złoto), lecz gdzie jedne elementy znaczące (siginifants) odnoszą się, bezustannie dryfując, do innych signifiants, uzyskując w ten sposób znaczenie tylko lokalne, względne i subiektywne. Jezzy - złota moneta epoki klasycznej, zastąiona została językiem, żetonem nowoczesności (J XC).

Iwaszkiewicz, co prawda, nie wprowadza wątku fałszywych pieniędzy, ale wiele jest sygnałów rozchwiania poczucia wartości pieniądza - najwyraźniej je widać, gdy Achilles, poinformowany o odziedziczeniu fortuny Wolffa, bez poczucia zażenowania prosi mecenasa (utrzymującego jego kochankę) o pożyczenie 2 złotych na taksówkę (I 130). Podjęcie przez Achillesa próby sprzedaży swojego zaangażowania (przyjaźni? miłości? ciała?) Wolffowi i następująca później - ostatnia - rozmowa, w której bohaterowie dyskutują o relatywizowanej wartości pieniądza, pozwalają wyrazić przypuszczenie, że mamy do czynienia z pewnego rodzaju naśladowaniem twórczym tematyki Fałszerzy. Mimo wszystko jednak ekonomia znaków-pieniędzy nie jest tak istotna w Przyjaciołach, jak w Fałszerzach. O wiele ważniejsza wydaje się kwestia piękna i jego reprodukowanie - prawie 10 lat przed słynnym esejem Waltera Benjamina zatytułowanego Dzieło sztuki $w$ dobie reprodukcji technicznej! - w opowieści symbolizowana przez „fałszywą Madonnę" (np. I 95) 68.

Zagadnienie „fałszywej Madonny”, które w artykule tylko sygnalizuję, nieuchronnie prowadzi nas ku kwestii tematycznego kręgu inspiracji Fatszerzami. Aby go omówić, wrócić musimy na chwilę do recenzji Eleutera $z$ „Wiadomości Literackich”. I tu dochodzimy do kwestii homoseksualności i do Korydona, oto bowiem tak pisze Iwaszkiewicz:

Jednym z podstawowych niedomagań tej powieści jest jej mętność ideowa. Książka zawiera pewne tezy, tezy te jednak po pierwsze nie grzeszą jasnością, po drugie są nieco pomieszane. Oczywiście najzrozumialej przedstawia się ta część nowej powieści, która jest jakby ilustracją teoretycznych założeń Corydona. Chodzi tu o zbawienny wpływ dobrej przyjaźni (na tle homoseksualistycznym) na rozwój charakteru młodzieży płci męskiej i na szkodliwość takiej przyjaźni - złej. Teza jasna sama przez się i dająca się wyrazić bez modnej okrasy miłości jednopłciowej, bez której nie może się teraz obyć ani jedna powieść francuska (Les Thibaults, Kyra Kyralina, La Bonifas, Faux-monnayeurs; no i Proust

Zob. np. J.-J. G o ux, Les Monnayeurs du langage. Paris 1984.

68 Być może, stanowi ona reminiscencję lekturową innej powieści A. Gide'a - Lochów Watykanu w których pojawia się postać (rzekomo) nieprawdziwego papieża. Jak komentuje J a ros z: „Nieprawdziwość papieża, ojca wspólnoty duchowej, autorytetu moralnego, który jako następca świętego Piotra, osobiście wyznaczonego na tę funkcję przez Chrystusa, powinien być gwarantem prawdziwości religii i istnienia Ojca Niebieskiego, budzi poczucie zwątpienia i wykorzenienia moralnego" (J LIV). 
oczywiście). U Gide’a występuje nawet matka, która czując, że jej ukochany syn poczyna się wymykać spod wpływów rodziny, powierza go człowiekowi, o którym wie, że czuje w swym sercu więcej niż przyjaźn dla jej syna, i jak gdyby błogosławi ów związek, widząc w nim szczęście swego dziecka ${ }^{69}$.

Dla Iwaszkiewicza Fałszerze wyznaczają możliwość pewnej fabularyzacji traktatu, jakim jest Korydon. Jak wiadomo (odnosi się do tego w recenzji także Iwaszkiewicz), w Fałszerzach widzimy dwie pary męskie na wzór antycznych par eromenos-erastes: Bernard-Edward i Olivier-Robert, $\mathrm{z}$ których ta pierwsza ma wzorcotwórczy charakter, najlepiej ilustruje to, o co chodziło protagoniście dialogów sokratycznych. U Iwaszkiewicza występuje jedna para, Wolff i Korecki, choć pewną rolę gra tu również postać preceptora Achillesa - ksiądz Gallieni. Niewiele o nim $\mathrm{w}$ gruncie rzeczy wiemy, ale przedstawiany on jest w pozytywnym świetle jako cierpliwy powiernik i doradca Achillesa, a przy okazji przeciwnik jego rodziców, wykazujący nieortodoksyjną tolerancję dla „podejrzanych” znajomości podopiecznego. Ich rozmowy czasami bardzo przypominaja te z Korydona:

- Więc ostatecznie nie chcesz miłości? Wierz mi, że to jest nierozsądny bunt przeciw naturze.

- Miłość się teraz tak często buntuje przeciw naturze.

- Czy tego cię też nauczył twój nowy przyjaciel? [...]

- Skąd ksiądz się tak zaraz domyślił?

- Domyśliłem się... Ale to także nieprawda, co pomyślałeś. Miłość prawdziwa nie może się buntować przeciwko naturze. Prawdziwa miłość wbrew naturze czy z natura jest zawsze miłością. [I 74]

Należałoby więc powiedzieć, że Przyjaciele są, sekundarnie, również próbą fabularyzacji założeń Korydona. W tej fabularyzacji istnieje jednak, jak sądzę, wyraźna intencja polemiczna - wyidealizowana relacja homoerotyczna (nawet jeśli platoniczna) między dorastającym chłopcem a dojrzałym mężczyzną, jaką postulował traktat Gide’a, jest niemożliwa w rzeczywistym świecie - tragiczny finał historii miłości/przyjaźni Wiesława Wolffa stanowi tego najlepszy dowód.

Abstract

WOJCIECH ŚMIEJA University of Silesia, Katowice

HOMOEROTISM, MIMESIS AND 'THE ART OF THE FUGUE' ANDRÉ GIDE'S CREATIVITY (“CORYDON," "LES FAUX-MONNAYEURS" 〈"THE COUNTERFAITERS”〉) IN POLISH INTER-WAR LITERATURE

The article presents the influence of André Gide's creativity over the mode of homosexuality representation in Polish Inter-war literature. It discusses literary pieces (S. I. Witkiewicz's Pożegnanie jesieni $\langle$ Farewell to Autumn〉), political commentary journalism (T. Boy-Żeleński), and correspondence (P. Hertz, J. Iwaszkiewicz). The second part of the sketch offers an insightful interpretation of Jarosław Iwaszkiewicz's short story entitled Przyjaciele (Friends) as a breakthrough story for Iwaszkiewicz's poetics and also as that which heavily relies on inspirations by Gide's Les Faux-monnayeurs (The Counterfaiters) of which Iwaszkiewicz was the translator. 